\title{
Writing the Wrong in the ELA Classroom: The Role of Performance Through Creative Writing
}

\author{
Petryna Venuta
}

\begin{abstract}
Why aren't English teachers creative writers? Why is there little to no emphasis on creative writing in ELA classes? What are the implications of popular media portrayals of the writer on students' perception of writing? In my classroom practice, I encouraged a variety of writing styles that allowed students to grow as readers, but, more importantly, as writers. This paper attempts to understand how we can integrate creative writing with traditional academic writing, to imagine its possibilities, and to examine how we can do more of it.

"Historians have constantly impressed upon us that speech is no mere verbalisation of conflicts and systems of domination, but that it is the very object of man's conflicts."

$\sim$ Michel Foucault (1972, p. 216)

"If you just read literature and never have the experience of trying to make it, it's a monument; but a writer knows that when it was being made, every word was debatable."

$\sim$ Wallace Stegner (quoted in Bunge, 1985, p. 78)
\end{abstract}

Performance in the English classroom, be it in the literal dramatic playing with text in a spoken word production, or the figurative working out of ideas and wordplay in the imaginative space of the student and creative direction of the teacher, is more necessary than ever. Students are inundated with performance through posed selfies, creating 15-second TikTok videos (or its precursor, the six-second Vine), and developing online personae. This Instagram lifestyle, itself a performance piece, need not be in direct competition for creativity in the classroom. And yet, we are in the throes of scripted and reality television shaping the way young people view the arts: singing competitions, dance competitions, and depictions of the reclusive, socially inept writer in films like Finding Forrester (2000) and Stranger Than Fiction (2008), or morally corrupt writers in films like Can You Ever Forgive Me (2018) and The Words (2012). Despite this host of inculcating realities, I, years ago, chose to combat incomplete portrayals, in a small but impactful way, with living realities: I took my grade twelve English classes to afternoons of professional productions of live theatre and evenings of author readings at the public library. On one such occasion, after an author reading and during the open question period, one student asked, "What is your best piece of advice for a young writer?" to which the visiting author, Farley Mowat, replied, "Put your foot through your tv." Though it is sage advice for writers who struggle to find the time and thinking space to write, teachers of high school writing recognize the need is to marry popular culture and media to creative writing and literature studies.

Even while in class, young people are bombarded with messages of instant gratification and supposed normalcy though their incessant use of social media and media multitasking (Lau, 2017). 
Teaching literature in this climate either attempts to divorce literacy from popular culture or overlap the modern world with the study of literature until both realms are blurred. It is a struggle to force the reader into a hiatus from the barrage and into a realm of quietude. This is why my method as a teacher, in order to slow down the liveliness but continue to excite the readership, was to expose my students to authors. We went to see many: Margaret Atwood, Alberto Manguel, Alastair McLeod, Douglas Coupland, Penn Kemp, André Alexis, and the aforementioned Farley Mowat, to name a few. My hope was to reveal what Rita Dove (1995) in her essay, For the Love of Books, experienced; Dove explains that she "had no living role models-a 'real' writer was a long dead white male usually with a white beard to match," but it was when she was in the eleventh grade that her English teacher took her "to a book signing in a downtown hotel" where she met John Ciardi. It was at "that moment [she] realized that writers were real people and how it was possible to write down a poem or story in the intimate sphere of one's own room and then share it with the world" (p. 122).

For one of my students in particular, Jessica-a strong maths student with no interest in sustained reading - attending an author reading ignited her love of reading. Our class had sat through an evening with Douglas Coupland at the city library's auditorium. When the final question was answered, and the applause had died, my students streamed out and headed back to their residence. Jessica, however, hovered around me as I packed up to leave.

"I want to talk to him," she said.

I told her that people would be lining up to get books signed so she would have to line up with the others.

"I don't have a book." She was crestfallen, and ready to bolt.

"I do." I took my copy of Hey Nostradamus! out of my bag and handed it to her. "For you. C'mon, let's go wait."

Although it was nearing midnight by the time Jessica arrived at the front of the line, she was animated and chatty. She engaged with Douglas Coupland, he signed her book, and she promised to read it. By the end of term, Jessica had read, written about, and presented on Hey Nostradamus! and had begun reading another Coupland novel.

Another student, Jason, who aspired to be a screenwriter, sent his final essay on Jon Tattrie's The Hermit of Africville to the author and was thrilled when Tattrie responded. Jason arrived to class one afternoon and announced, "A writer wrote to me! A writer read my essay about his book!"

Furthermore, Carl Leggo (1997) experienced the chasm between education and readership:

As a student in school I believed that poetry was written by dead men who had lived in faraway countries. I also believed that poetry was about grand themes of love and war and heroism and religion and nature. Moreover, I thought that poetry was a puzzle-obscure, ambiguous, and convoluted - that I could never solve. I never wrote poetry in school because poetry was written by people with gifts for rhyme and rhythm, and I was convinced I had none (p. 7). 
In the classroom, I wanted my students to feel the nearness of poetic experience. When Penn Kemp came into our room to deliver her sound poems and have students participate in choral readings, the students began to recognize the living breath of reciting poetry, and of the poet herself. One can imagine, then, after crafting and implementing writing lessons, the excitement I felt when four of my students became published poets in Possessions: The Eldon House Poems (Hoogland \& Walde, 2010) while writing and submitting during my course. Two of them were granted the further pleasure of performing their piece for an audience during the book launch at the London Museum's Eldon House while another was featured in the local paper.

One of these student poets, Yun $\mathrm{Wu}$, demonstrated the powerful shift from othering to becoming —an important resituating when writing as a response to reading moves toward writing creatively within diverse personae. Yun Wu's poem, "Through the Pale Green Curtain," puts the writer inside the experience of a witness to a Victorian household: "Bells tinkled in the kitchen/Servants held out the porcelain tea set" and "I was wandering, a player caught in some naughty kid's/Game of hide and seek." Despite having few instructions on the assignment, Yun Wu wrote a lyric poem from a class field trip to a local museum while "she watched the snow dancing in waltz step."

This issue — creative writing in the literature classroom — is important because students who are beginning to read and write critically in all subject areas, require, above all, creative thinking skills. Creative writing improves understanding through closer readings of the text (Broekkamp, Janssen, \& Van Den Bergh, 2009). Indeed, when we compose, be it academic or creative work, we continue to combine, edit, build, and adjust as we write (Smagorinsky \& O'Donnell-Allen, 1998), for writing is itself a process separate from reading or discussing (Gardner, 1983). It was with this ideology that I brought writing into the classroom.

Because the study of literature is "interwoven with studies in linguistics, anthropology, sociology, history, psychoanalysis, philosophy, and politics" (Leggo, 1997, p. 8), students, who are learning to be world citizens, need to appreciate that writing, and exploring, is available to them, and necessary for them. The main thrust for the study of literature in senior English classrooms, and beyond into university, is to shape critical readers; it is my position that it is not only creative writing that is being neglected, but also a whole host of its benefits.

It is time we move away from teaching English as reading skills and writing in a reporting way. When students develop identities as confident meaning-makers, they will be less "reliant on technique spotting" (Lockney \& Proudfoot, 2013, p. 158). We ought to be teaching reading as art teachers train students-by mirroring styles, nurturing myriad points of view, and practising, practising, practising. If we are to build a world wherein we strive to understand and accept_-indeed, celebrate_-our cultural differences and ideological divergences, then we must allow the assuming of various personae within our creative writing (becoming) rather than responding to reading (othering). Writing narrative promotes identity construction/self-awareness, and awareness of others' positions. If we are to better understand our own position, one another, and, ultimately, become world citizens, we need to see creative writing as a way to help students dig deeper into their understanding of a text. 


\section{English Teachers Are Effective Readers}

What we do when we read, however "natural" it seems, presupposes a whole theoretical discourse, even if unspoken, about language and about meaning, about the relationships between meaning and the world, meaning and people, and finally about people themselves and their place in the world. (Belsey, 1980, p. 4)

English is the study of literature, literary analysis, professional writing, and creative writing. More often than not, however, the emphasis is on developing effective reading and reporting skills (Gannon \& Davies, 2007; Hogue, 2011; Elbow, 1999). Moreover, writing is deemed, across departments, to be the domain of the English Department (Isaacs, 2009). In a study conducted in 2007 on whether students in English teacher training programs identified themselves as writers:

73 students wrote prose responses to the open-ended question: 'Why do you want to become an English teacher?' [...] [H]alf the students said that their primary motivation was a love of reading, especially literature. Only ten of 73 mentioned a love of writing in their responses. Reading is the mode that invites English teachers in to the profession and that incites their passions. (Gannon \& Davies, 2007, p. 91)

Since most teachers identify themselves as readers rather than writers (Antoniou \& Moriarty, 2008; Rubin \& Kirby, 1982; Green, 2009), creative writing is often neglected in the literature classroom, even though reading ought to reveal aspects of life with which we are unfamiliar. This is the dichotomy, then: how are we to bridge building understanding neglected by the reader's lens and sense of self-actualization when we only offer one stem of learning?

\section{Why Aren't English Teachers Writers?}

"Why do people who write continue to teach (thus disrupting the myth that says those who can, do; those who can't, teach)?" (Gannon \& Davies, 2007, p. 88)

As Gannon and Davies (2007) point out, "few English teachers are simultaneously 'writers' in any sustained, pleasurable or publicly successful ways" (p. 87). Frager (1994) reminds us that by examining "teachers' perceptions of themselves as writers, we may understand more about how teachers' writing ability affects their work" (p. 275). In his 1994 study, he found that only six of 26 teachers in a writers' workshop believed that writing was an integral part of their identities and lives (p. 275).

We read to glimpse a life we cannot or are not living. To better understand our fellow beings. To gain sympathetic insight by peeking into the imagination of others. However, even though we speak as though we witness the main character or are surrounded by the setting, all reading is passive observation, and most writing that literature classes impose on students is reporting on that reading. This kind of writingobserving and reporting on our particular observations-perpetuates "othering." If we are to cultivate an education that encourages myriad perspectives, cultures, understandings, and truths, then we must motivate our students to write creatively. Creative writing does not report-it engages. Creative writing forces the writer to assume the point of view of the subject material. It stimulates "becoming." Reporting on Hamlet is quite different from writing Ophelia's private journals, writing an offstage dialogue between 
Gertrude and Claudius, or writing Hamlet's letters from university to his father. This is especially important for social issues - the danger, of course, is assuming roles for which we cannot know-but this is easily rectified by the assigned task.

One former student, Wushuang Deng, wrote in 2011 in the school's newsletter, that defining himself had been elusive in his teen years:

How surprisingly, then, it was for a young man who used to dislike literature to be enchanted by those literary masterpieces? Everything has changed since I attended my grade twelve English course at London International Academy, taught by Ms. Venuta. She gave students independent approaches to secure knowledge and I found my learning experience increasingly piqued every time I dove into the context. More importantly, the course was not simply and solely confined to books but virtually went beyond itself as we applied the theses to our real lives. With passion leading the way, following my heart, I learned how to make the best decisions for myself during the fleeting life course.

Since English teachers are prone to offer reading strategies rather than writing activities, the possible benefits of creative writing are often overlooked, and easily dismissed, possibly because of the need to provide practical, job-oriented skills (Austen, 2005), but probably because many teachers are suspicious of the value of creative writing (Green, 2009); "creative writing courses are often perceived by students and faculty as peripheral courses to be taken only if one has time for fun in his/her schedule" (Austen, 2005 , p. 138). And yet, "more than $75 \%$ of the examples of good writing chosen by leading teachers in 1986 for the book What Makes Writing Good were autobiographical pieces that emphasized personal revelation and reflection" (Dyer \& Friederich, 2012, p. 267).

No one disputes that the subject position of English teacher entails a "love" of reading (Peel, Patterson, \& Gerlach, 2000), however, there is no corollary with writing. Few English teachers are simultaneously "writers" in any sustained, pleasurable, or publicly successful ways; Rubin and Kirby (1982) point out:

High school students learn about grammar, about literary genres and history, about types of writing. They do not, as a rule, learn to use grammar, to respond with literature, to engage in writing in the course of coming to grips with the substantive world. (p. 41)

In a more specific light, Grossman (1989), in A Study in Contrast: Sources of Pedagogical Content Knowledge, investigates the influence of subject-specific coursework in the development of pedagogical content knowledge in English through contrasting case studies of six novice English teachers, only three of whom graduated from teacher education. Throughout her investigation, she disparages non-teacher trained Jake, whose goals, while teaching Hamlet, were for his students "to have them see the interconnections among the themes of the play, to learn the skills involved in textual analysis" (p. 24), and includes assignments of "an in-class analysis of one soliloquy, memorization and recitation of a soliloquy, a five-page paper on any theme in Hamlet, and a final exam" (p. 24). The contrast is provided with her celebration of teacher-trained Steve, whose class watched film clips of various productions, and wrote an essay that compared modern sensibilities to Hamlet's, and yet, "During this time, the students never read the play itself" (p. 24). To imagine that there are only these two binary possibilities seems as 
effective as teaching cursive writing with a glow stick and with—if the students are lucky—the lights turned off.

My method was a performative one. I tasked students to rewrite a scene from the play in their own words but maintain the sense and motivation of the scene. They also had to prepare a backdrop using PowerPoint slides, costumes, props-and write a journal describing the group work experience. The results were tremendous: tumbling clowns for kings and advisors to the king, all-female casts to reveal deeper or alternate meanings of the text, and futuristic final scenes replete with lightsabers and capes. Students were also tasked to complete the traditional academic essay, but it must be emphasized that creative thought, critical thinking, along with observing and reporting, are all vital skills for students and can be built most thoroughly when myriad writing skills are practised.

When I handed over the script I had written for The London One Act Festival to my students to direct, perform, design, and stage, I had not suspected the impact it would have on them. Every word, name, characterization, and stage direction became alive and questionable to them. They asked questions, made notes, and grew before a live, paying, local audience. One student, after graduating, wrote to the school principal saying:

I was excited and nervous, as I was a novice in this field. However, the tough job can be solved by appropriate means. Communication, one of the most useful methods I found, helped me compile information and advice together. Thus, the show was successful, and I felt that I was growing more and more confident. (personal communication, October 26, 2011)

\section{Penning the Writers}

To try such writing oneself, and thereby to gain the authority of 'textual power' is to remove much of the threat [or in the terms already expressed in this paper, much of the awe, or fear, of literature] for teachers and students alike. (Bloom, 1998, p. 5)

Dance teachers are dancers. Art teachers are artists. Music teachers are musicians. Why, then, are not Literature teachers writers? As Jay Parini (1994) notes, "for such literary figures as Ben Jonson, John Dryden, Samuel Johnson, William Wordsworth, Samuel Taylor Coleridge, Matthew Arnold and T.S. Eliot, '[t]he critical and creative aspects of their writing co-existed happily in the same imagination'" (quoted in Austen, 2005, p. 139). If we offer students the pen and allow them to explore the positionality of the writer, students will gain insight into the weight of the word, the search for meaning, and the decision-making process that shapes creative writing. Creative writing is as arduous and serious as academic writing (Kingsley, 2007), though by neglecting it in the classroom, we have allowed it to be seen in one of two ways: on one hand, creative writing as mysterious and impenetrable, or, on the other, as made by the mind consumed with, as is seen in film, madness. No one expects that we will create a classroom of writers any more than we expect a biology classroom to be peopled with future biologists, but by positioning students as the producers of literary writing reflects the dominant goal of ensuring that our students take on active roles in our classrooms (Austen, 2005; Green, 2009). 


\section{Creative Writing: Discovery and Invention}

Writing literature to learn literature obliges and enables the students to become invested in their own writing, and in the writing of their peers, in ways they would never have imagined before they tried it. The students fret. They stew. They write and rewrite and rewrite again before they're ready to share their work with me and with each other. (Bloom, 1998, p. 58)

Part of the problem of cultivating a creative writing component to the senior is classroom is, as Rubin and Kirby (1982) point out, that "English teachers who face 140-160 students each day, quarter after quarter, despair of their limited ability to provide the time and individual attention students need to progress in writing ability" (p. 44). We must begin with Rosenblatt's (1994) "transactional approach" to literature studies - one that combines the reading of literature with both essay writing and creative writing. Leggo (1997) draws a lovely analogy of this experience:

Too often students' experiences in poetry classes are similar to my experiences in driving school. For four Saturdays I sat in a classroom and listened to lectures and watched films that depicted the driving process in intricate detail. My first experience behind the wheel of a real car was a shock. I understood the mechanics of driving and had driven hundreds of miles in my imagination, but suddenly realized that I could not drive. Too many poetry classes operate around the model of my driving school experience. The teacher creates an artificial environment in which readers are granted entry to the poetic text through the door of his or her perspective. Armed with a battery of notes and a special guidebook, the teacher gives a lesson designed to manipulate the students to reiterate the teacher's encounter with the poem in the hope that meticulous and appropriate attention to two dozen poems a year will prepare the reader for reading poetry with satisfaction and enthusiasm. (p. 7)

According to David Bartholomae (1985), this divide can be lessened using activity-specific approaches; for example, "When students are writing for a teacher, writing becomes more problematic than it is for the students who are describing baseball to a Martian" (p. 277). Peter Elbow (1999), for his part, is not making an exclusive case for teaching writing about literature over anything else; he suggests that firstyear writing students would benefit from more work in writing with metaphor and imaginative language. Veronica J. Austen (2005), at The University of Waterloo, states that there are five benefits of incorporating creative writing activities into English literature courses:

(1.) Dispelling the awe of literature and creating active learners; (2.) Developing critical readers;

(3.) Furthering student understanding of literary criticism; (4.) Inspiring deeper commitment to excellence; and (5.) Motivating class bonding and dismantling the classroom hierarchy. (p. 139)

Her arguments are at once compelling and convincing. As she expands her argument, giving credence to each of her five benefits, Austen purports that creative writing assignments will foster a closeness to the text that academic writing cannot; students will take ownership, will weigh their words, will search and find symbolic meaning, and she adds even assignment design and assessment. Clearly, it is able to come to fruition, but it seems to require a lot of convincing and cajoling on the part of those who agree to get those on board who do not agree.

In a similar vein, Margaret Atwood's early involvement in an exciting project on Wattpad (an interactive online writing page) whereon she contributed to the popular phenomena of the Zombie in a short 
collaboration examines performance in collaborative writing. She applauds the Internet's ability to open writing to all who are interested: "Suppose you're a young person in a developing country," she told The Next Chapter's host Shelagh Rogers in an interview,

You don't have a school, you don't have a library, you don't have a bookstore, you don't have paper books, you don't have a tablet computer ... But you've got a cheap cell phone. You can read on your phone, you can write on your phone. (Rogers, 2012)

In order to engage students with the possibilities available to them, and to further their understanding of myriad course material in all departments, we must cease to think of creative writing as having less intellectual rigour than essay writing; we must come to recognize creative writing as a critically engaging activity that provokes students to become close readers and advances their understanding of literary criticism. In fact, part of the attraction of including creative writing activities is that they allow students, as George Marsh (1992) expresses, to "illuminate criticism by learning experientially about the construction of a text" (quoted in Austen, 2005, p. 142).

We must move beyond simple memorization of literary terms, theories, and schools of criticisms to the machine of applying these facts into the fabric of the students' lives, ideas, opinions, and perspectives. Creative writing can offer so many of these opportunities.

\section{Why Creative Writing Is Important in the Classroom}

The political enters the study of English primarily through questions of representation: who is represented, who does the representing, who is object, who is subject - and how do these representations connect to the values of groups, communities, classes, tribes, sects, and nations? (Scholes, 1985, p. 153)

Creative writing serves the student's ability to share, negotiate, and exchange power dynamics. Power structures and the inequality of the relationships between colonizer and colonized is a dominant theme in Western literature. Creative writing exercises offer strategies of seeing more deeply into the lives of others. In Creative Writing, Contemporary Theory and the English Curriculum, Miles (1992) explores how creative writing serves both to enhance a student's understanding of theoretical constructs and to develop the skills of close reading. In other words, creative writing demands that students pay careful attention to the effect of their words. This attention to detail can transfer to their reading. As Miles suggests, the "practical element [of creative writing] encourages close reading, an attentiveness to the peculiarities of form" (pp. 43-44). Once students understand the challenge of making their writing both interesting and meaningful, they will come to recognize the efforts in the writers being studied. Therefore, through this practical experience of creating literary works, students will come to appreciate the techniques used in the literary texts they read and, thereby, become further motivated to read closely. 


\section{The Implications of the Depiction of the Writer in Western Literature}

In George Eliot's single drop of trembling ink, ${ }^{1}$ William Makepeace Thackeray's master puppeteer, ${ }^{2}$ and Thomas King's fluid storyteller in concrete prose, ${ }^{3}$ depictions of the writer is the vehicle propelling the narrative to fruition-thereby creating the universe. But in others, like Haruki Murakami's fiction, ${ }^{4}$ the storyteller is carried by the action-being created by the universe. The writer in some literature seems to hold a dichotomous position; either the writer is an esteemed artist living outside, indeed above, the wildness of everyday activity, or they are a bedraggled lunatic, trapped within the furious storm of human life. The artist figure in Alfred, Lord Tennyson's Lady of Shalott (1833), for instance, is a creator embowered in a mirrored universe even though it cannot sustain her in real time. Michel de Montaigne's tower, ${ }^{5}$ too, and his self-reflecting prose, allow him to both see and be seen without lowering himself to live interaction. But take, on the other hand, the creative Madame Reisz in Kate Chopin's attic, ${ }^{6}$ reduced to being both abhorred and mocked by her community. Take also Michael Douglas's portrayal of a writer in the film Wonder Boys (2000) or Sean Connery's rendering in Finding Forrester (2000) —both are scraggly, defeated talents reduced to moral or social deviancy. According to bell hooks (1996), film can perform a pedagogical function by providing a "common starting point from which diverse audiences can dialogue about...charged issues" (p. 2); but, even further, these images help define our culture's ideas of normalcy. This has greater implications than simply developing our collective idea of a writer.

As a secondary school English teacher, I have witnessed how reading is overemphasized. While students are trained to be critical readers, they are not taught to be creative thinkers or writers. Responding to literature in creative ways would help the student to become a critical reader. If the student saw through the lens of the writer, shaping the prose with Saussure ${ }^{7}$ on the shoulder whispering significations of shapes and sounds s/he would gain greater insight into the weight of the word. If the student were to sweat and twist out words like Fitzgerald's Carraway ${ }^{8}$ or Camus's Sisyphus-ian Stranger, ${ }^{9}$ each all-seeing though less sighted than Eckleberg's faded advertisement, ${ }^{10} \mathrm{~s} /$ he would have a keener eye to identifying symbol, metaphor, and plot. If students could develop their own positionality, they would be adept at seeing the female writer herself, having finished Virginia Woolf's dishes ${ }^{11}$ while still rubbing Charlotte Perkins Gilman's yellow wallpaper ${ }^{12}$ off her shoulder. The student may be repelled by the depictions of the author in Western literature, even of those images that drive the narrative like the transcendentalist Ralph Waldo Emerson's transparent eyeball ${ }^{13}$ or the modernist T. S. Eliot's socially awkward Prufrock, ${ }^{14}$ but we must allow them the opportunity to drive their own narrative because depictions of the writer in literature are defining our students, and, perhaps, even limiting our collective perception of the arts, of performance, and of scholastic achievement.

We must be prepared to allow students to negotiate their interpretations of meaning in their readings through creative lenses. They must be encouraged to write for this feeling of entitlement, of autonomy, of power and of privilege, can only serve to help students in their academic work, their self-knowledge, and feelings of satisfaction. By motivating our students through writing, we will be ensuring that our students gain a deeper understanding of the literary texts studied in class. The direct instruction model of education, which provides students with the teacher's own interpretation of the texts, may be efficient, but it breeds student apathy. It can be challenging to get students to take the time to pay attention to each 
word, phrase or sentence and how it functions to create meaning; however, because students often treat creative assignments as an expression of their inner, secret selves, they begin to recognize the weight of their words. Though the media threatens to divorce understanding from the craft of various arts, we can allow students to see that, contrary to images from singing and dancing competitions portrayed on television, creativity and artistic motivations are built stone by stone, rather than in an overnight leap. We have to allow students to take ownership in their own learning.

\section{Notes}

1. In Adam Bede (1859)

2. In Vanity Fair (1847)

3. In The Truth About Stories (2005)

4. In, for example, Norwegian Wood (1987) and The Wind-Up Bird Chronicle (1997)

5. In his Essays (1580)

6. In The Awakening (1899)

7. In Writings in General Linguistics (1907-1911)

8. In The Great Gatsby (1925)

9. In The Stranger (1942)

10. The Great Gatsby

11. A Room of One's Own (1929)

12. The Yellow Wallpaper (1892)

13. In Nature (1836)

14. In The Love Song of J. Alfred Prufrock (1915)

\section{References}

Antoniou, M., \& Moriarty, J. (2008). What can academic writers learn from creative writers? Developing guidance and support for lecturers in higher education. Teaching in Higher Education, 13(2), 157-167.

Austen, V. J. (2005). The value of creative writing assignments in English literature courses. International Journal for the Practice and Theory of Creative Writing, 2(2), 138-150.

Bartholomae, D. (1985). When a writer can't write: Studies in writer's block and other composing process problems. Guilford. 
Belsey, C. (1980). Critical practice. Methuen

Bloom, L. (1998). Composition studies as a creative art: Teaching, writing, scholarship, administration. Utah State University Press.

Broekkamp, H., Janssen, T., \& Van Den Bergh, H. (2009). Is there a relationship between literature reading and creative writing? Journal of Creative Behavior, 43(4), 281-297.

Bunge, N. L. (2005). Master class: Lessons from leading writers. University of lowa Press

Dove, R. (1993). Selected poems. Pantheon.

Dyer, B., \& Friederich, L. (2012). The personal narrative as cultural artifact: Teaching autobiography in Japan. Written Communication, 19(2), 265-296.

Elbow, P. (1999). In defence of private writing: Consequences for theory and research. Written Communication, 16(2), 139-170.

Foucault, M. (1972). The discourse on language. In The archeology of knowledge and the discourse of language (Trans. A.M. Sheridan Smith). Pantheon Books.

Frager, A. M. (1994). Teaching, writing, and identity. Language Arts, 71(4), 274-278.

Gannon, S., \& Davies, C. (2007). For love of the word: English teaching, affect and writing. Changing English, Vol. 14, No. 1, April 2007, 87-98.

Gardner, H. (1983). Frames of mind: The theory of multiple intelligences. Basic Books.

Green, A. (2009). Creative writing in A level English literature. International Journal for the Practice and Theory of Creative Writing. Vol. 6, No. 3, 187-195.

Grossman, P. L. (1989). A study in contrast: Sources of pedagogical content knowledge for secondary English. Journal of Teacher Education, September-October, 24-31.

Hogue, B. (2011). I'm not making this up: Taking humor seriously in the creative nonfiction classroom. Pedagogy, 11(1), 199-205.

Hoogland, J., \& Walde, C. (Eds). (2010). Possessions: The Eldon house poems. Museum London.

hooks, b. (1996). Reel to real: Race, sex and class at the movies. Routledge.

Isaacs, E. (2009). Teaching general education writing: Is there a place for literature? Pedagogy, 9(1), Winter 2009, 97-120.

Kingsley, J. (2007). Literacy instruction in a constructivist elementary classroom: A qualitative inquiry (Doctoral dissertation, McGill University, 2011). McGill University Libraries.

Lau, W. (2017). Effects of social media usage and social media multitasking on the academic performance of university students. Computers in Human Behavior, 68, 286-291. doi:10.1016/j.chb.2016.11.043

Leggo, C. (1997). Teaching to wonder: Responding to poetry in the secondary classroom. Pacific Educational Press. 
Lockney, K., \& Proudfoot, K. (2013). Writing the unseen poem: Can the writing of poetry help to support pupils' engagement in the reading of poetry? English in Education, 47(2), 147-162.

doi:10.1111/eie.12017

Miles, R. (1992). Creative writing, contemporary theory and the English curriculum.

Open University Press.

Rogers, S. (Producer). (2012). The next chapter. CBC Radio.

Rosenblatt, L. (1994). The reader, the text, the poem: The transactional theory of the literary work. Southern Illinois University Press.

Rubin, D. L., \& Kirby, D. R. (1982). Training secondary school teachers of writing. Journal of Teacher Education, 33(5), 41-45.

Scholes, R. (1985). Textual power: Literary theory and the teaching of English. Yale University Press.

Smagorinsky, P., \& O'Donnell-Allen, C. (1998). Reading as mediated and mediating action. Composing meaning for literature through multimedia interpretive texts. Reading Research Quarterly, 33(2), 198-226.

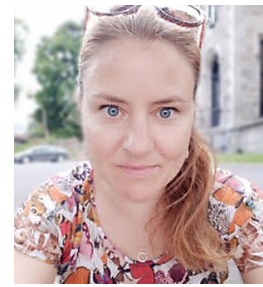

Petryna Venuta is a PhD student at McGill University. She has taught English in Ontario high schools for 15 years, in public and private schools. She is also a playwright, having had plays staged with The Grand Theatre's Playwrights' Cabaret and The London One Act Festival. Her poetry has been displayed on city buses during a Poetry In Motion campaign, and her short stories have appeared in literary journals. She was also a finalist in the Malahat Review's Novella contest. 